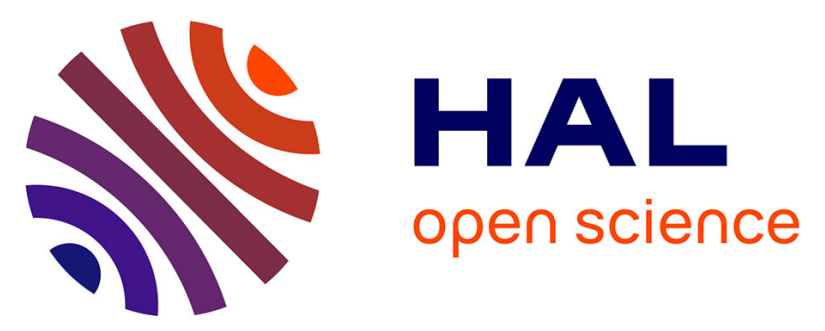

\title{
Uterine bacterial flora in postpartum Danish Holstein dairy cows determined using DNA-based fingerprinting: Correlation to uterine condition and calving management
}

Karina Elkjaer, Marie-Louise Ancker, Hans Gustafsson, Nicolas N.C. Friggens, Andres Waldmann, Lars Molbak, Henrik Callesen

\section{To cite this version:}

Karina Elkjaer, Marie-Louise Ancker, Hans Gustafsson, Nicolas N.C. Friggens, Andres Waldmann, et al.. Uterine bacterial flora in postpartum Danish Holstein dairy cows determined using DNAbased fingerprinting: Correlation to uterine condition and calving management. Animal Reproduction Science, 2013, 138, pp.39-48. 10.1016/j.anireprosci.2013.01.016 . hal-01186807

\section{HAL Id: hal-01186807 https://hal.science/hal-01186807}

Submitted on 28 May 2020

HAL is a multi-disciplinary open access archive for the deposit and dissemination of scientific research documents, whether they are published or not. The documents may come from teaching and research institutions in France or abroad, or from public or private research centers.
L'archive ouverte pluridisciplinaire HAL, est destinée au dépôt et à la diffusion de documents scientifiques de niveau recherche, publiés ou non, émanant des établissements d'enseignement et de recherche français ou étrangers, des laboratoires publics ou privés. 


\title{
Uterine bacterial flora in postpartum Danish Holstein dairy cows determined using DNA-based fingerprinting: Correlation to uterine condition and calving management
}

\author{
K. Elkjær ${ }^{\mathrm{a}, \mathrm{b}, *}$, M.-L. Ancker ${ }^{\mathrm{a}}$, H. Gustafsson ${ }^{\mathrm{c}}$, N.C. Friggens ${ }^{\mathrm{d}, \mathrm{e}}$, A. Waldmann ${ }^{\mathrm{f}}$, \\ L. Mølbak ${ }^{g, 1}$, H. Callesen ${ }^{\text {b }}$ \\ ${ }^{a}$ Knowledge Centre for Agriculture, Skejby, 8200 Aarhus N, Denmark \\ ${ }^{\mathrm{b}}$ Department of Animal Science, Aarhus University, 8830 Tjele, Denmark \\ c Swedish University of Agricultural Sciences, Faculty of Veterinary Medicine and Animal Science, Department of Clinical Sciences, 750 \\ 07 Uppsala, Sweden \\ d INRA UMR 791 Modélisation Systémique Appliquée aux Ruminants (MoSAR), AgroParisTech, 75231 Paris Cedex 05, France \\ e AgroParisTech UMR 791 Modélisation Systémique Appliquée aux Ruminants, 16 rue Claude Bernard, 75231 Paris, France \\ ${ }^{\mathrm{f}}$ Estonian University of Life Sciences, Institute of Veterinary Medicine and Animal Sciences, Department of Reproductive Biology, 51006 \\ Tartu, Estonia \\ ${ }^{g}$ National Veterinary Institute, Technical University of Denmark, 1790 Copenhagen V, Denmark
}

\section{A R T I C L E I N F O}

\section{Article history:}

Received 19 January 2012

Received in revised form 16 January 2013

Accepted 29 January 2013

Available online 9 February 2013

\section{Keywords:}

Uterus

Bacteria

T-RFLP

Metritis

\begin{abstract}
A B S T R A C T
The overall aim of this study was to describe uterine bacterial flora during the postpartum period in Danish Holstein cows using the Terminal Restriction Fragment Length Polymorphism (T-RFLP) method. This method produces a pattern of nucleic acid fragments from the microorganisms present, reflecting the "fingerprint" of the actual microbial flora. As well as characterizing changes in flora with time from calving and between herds, data were examined for strong relations between uterine bacterial flora, calving management and uterine condition. In total 125 Holstein cows from five herds were included, and for each cow calving management was recorded. Cows were clinically examined on average 8 (range 0-19) and 28 (range 22-38) days after calving, and a uterine sample was taken for bacterial identification using T-RFLP. Milk samples were taken weekly for progesterone analysis. Bacteria were found in all cows at both examinations, and the flora was composed of many species, including species not traditionally reported to be present in the bovine uterus. The bacterial composition differed according to days from calving and herd. In all five herds Fusobacterium necrophorum, Pseudomonas/Acinetobacter and Bacteroides/Sphingobacterium/Prevotellaceae were among the most common at both examinations. In four herds there was a percentage decrease of $F$. necrophorum from first to second examination, and in all herds there was a percentage increase of Pseudomonas/Acinetobacter from first to second examination. No differences in bacterial flora were found between cows with different uterine scores, which were influenced by herd, calving difficulty and retained placenta.
\end{abstract}

(c) 2013 Elsevier B.V. All rights reserved.

\footnotetext{
* Corresponding author at: Knowledge Centre for Agriculture, Agro Food Park 15, Skejby, 8200 Aarhus N, Denmark. Tel.: +45 87405304.

E-mail address: kae@vfl.dk (K. Elkjær).

1 Present address: Chr. Hansen, Boege Allé 10-12, 2970 Hoersholm, Denmark.
}

\section{Introduction}

In cows with a normal puerperium, prevalence and consequences of bacteria in the uterine lumen is debated. In some studies bacterial cultures were found in a high proportion of puerperal cows (Elliott et al., 1968; Griffin 
et al., 1974; Hussain et al., 1990) while in other studies they were not (Bekana et al., 1996; Fredriksson et al., 1985; Noakes et al., 1991). Prevalence rates of Streptococci spp. and Staphylococci spp. may be greater in cows with uncomplicated postpartum (p.p.) period, indicating a sort of 'normal' uterine flora (Huszenicza et al., 1999). From cows with abnormal uterine conditions, bacteria as Escherichia coli, Arcanobacterium pyogenes and gram negative anaerobes (e.g. Bacteroides spp. and Fusobacterium spp.) are more often isolated (Santos et al., 2011; Sheldon et al., 2008; Werner et al., 2012); such bacterial flora is characterized as "contamination" or "infection" (Sheldon et al., 2002). Among pathogenic bacteria, A. pyogenes is often related to a serious effect on reproduction (Griffin et al., 1974; Huszenicza et al., 1999; Williams et al., 2005). In some studies the bacterial flora in the uterus of cattle changes in composition and amount within the first weeks after calving (Bekana et al., 1996; Dolezel et al., 2010; Hussain et al., 1990). It remains to be shown if knowledge of the uterine bacterial status of a cow during the first two weeks p.p. can be used to indicate her risk of a prolonged p.p. anovulation.

Bacteria have traditionally been classified using bacterial culture. However, as some bacteria are easier to grow than others (Amann et al., 1995), and as some will be overwhelmed by others, a culture period can shift the flora from time of sampling to time of reading the culture result. Elliott et al. (1968) stated that six different growth-media should be used to detect all organisms in the bovine uterus at various times after calving, but this has rarely, if ever, been done in subsequent studies (Bekana et al., 1996; Griffin et al., 1974; Noakes et al., 1991). Several culture-independent methods for identifying and characterizing the microbiological communities of different environments are therefore now applied, also in studies of the bovine uterus (Santos et al., 2011; Sheldon et al., 2010; Silva et al., 2009). One such method is the Terminal Restriction Fragment Length Polymorphisms (T-RFLP) method that produces a pattern of nucleic acid fragments (TRFs) from all microorganisms in the sample, reflecting the "fingerprint" of the actual microbial flora (Kitts, 2001). If this does not result in a clear identification of the organism, DNA cloning and sequencing may be the next step. The final result is a picture of the bacteria present in the sample, including those difficult to grow (Amann et al., 1995; Kalmbach et al., 1997).

One important factor for infection risk may be hygienic conditions and cow management around calving, including cleanliness of the calving pen and routines regarding calving assistance. Very few studies have focused on this (Noakes et al., 1991; Potter et al., 2010), and how management practices affect uterine bacterial flora is not known for certain. Furthermore, the extent to which the uterine bacteria composition depends on the cow's herd has not been studied.

The overall aim of this study was to describe the uterine bacterial flora during the p.p. period in Danish Holstein cows using the T-RFLP method. The hypothesis was that a certain bacteria composition, assessed by the T-RFLP method, was associated with the appearance of the vaginal discharge. As well as characterizing changes in flora with time from calving and between herds, data were examined for strong relations between the uterine bacterial flora, calving management and uterine condition.

\section{Materials and methods}

\subsection{Study farms}

The trial was conducted from October 2008 to January 2009 in five herds with Danish Holstein cows. Four of the five herds were commercial farms, selected within the same veterinary practice with a standardized herd health agreement with weekly veterinary visits and routine examinations of fresh cows. The four commercial herds were chosen from a larger pool of herds according to occurrence of metritis (to obtain a variation in pathological picture), and based on the willingness of the herd owners to participate (to obtain the best possible registrations). Two herds (Herds 1 and 2) with a lesser incidence of metritis (7.9\% and $12.6 \%$, respectively) and two herds (Herds 3 and 4 ) with a greater incidence of metritis $(21.4 \%$ and $20.9 \%$, respectively) were chosen. The fifth herd was the research farm connected to Aarhus University and had a lesser metritis incidence at $6.0 \%$. The herd size was $140-400$ cows, and the milk yield was $9500-11,000 \mathrm{~kg}$ ECM/cow per year.

\subsection{Animals and records}

The first 25 cows that calved in each of the five herds after the start of the trial period were selected for this study, so a total of 125 cows of Parities $1-8$ were included in the study. To standardize the clinical procedures and reporting of findings, all participants received standard instructions at the beginning of the study. All individual cow data were recorded directly for this study using a special protocol or through the Danish Central Cattle Database.

Calving management was evaluated by the farmer for every calving by the following parameters: use of calving pen, number of cows in the pen at calving (single or more), whether clean bedding was provided in the pen before calving, whether cleaning or disinfection of the pen was conducted before calving, and the time the cow spent in the calving pen before calving (coded as: $1=$ moved to calving pen immediately before calving; $2=$ moved $12 \mathrm{~h}$ before calving; $3=$ moved $24 \mathrm{~h}$ before calving, $4=$ moved more than $24 \mathrm{~h}$ before calving).

Calving date, calving difficulty and calf survival as well as time to fetal membrane detachment were recorded by the farmer. Calving difficulty is a mandatory registration for Danish farmers and is entered into the Danish Central Cattle Database. Farmers recorded calving difficulty using one of the five categories: 1 =easy calving with no assistance, 2 =easy calving, but with the farmer's assistance, 3 = difficult calving without veterinary assistance but with farmer's assistance, 4 =difficult calving with veterinary assistance, 5 = cesarean section. For evaluating calf survival two categories were used: $1=$ living calf, $2=$ stillborn or dead within the first $24 \mathrm{~h}$ after delivery. All cows gave birth to single calves and without any cesarean section.

Retention of the fetal membranes for more than $12 \mathrm{~h}$ was treated by manual removal of the placenta, and 
antibiotics were only used if the cow was ill, based on lack of appetite and increased rectal temperature $\left(>39.5^{\circ} \mathrm{C}\right)$. Systemic treatment was with oxytetracycline and was preferred to avoid placing antibiotics directly into the uterine lumen. If the cow had a retained placenta, the uterine sample was taken immediately before removal of the placenta. In total six cows were treated for retained placenta, and these cows were distributed across all herds. Metritis was defined according to the definitions of puerperal metritis and clinical metritis by Sheldon et al. (2006). Only cows defined as having puerperal metritis (abnormally enlarged uterus, watery foul-smelling discharge with signs of systemic illness and fever $>39.5^{\circ} \mathrm{C}$ within 21 days after calving) were treated, and antibiotics were only used systemically. Metritis treatment was with oxytetracycline and, if needed, non-steroidal anti-inflammatory drugs. If a uterine sample was to be taken on the same day as treatment, this was always done immediately before the treatment. In total 11 cows were treated for metritis (two in Herd 1, three in Herd 2, three in Herd 3, two in Herd 4, one in Herd 5). Four of these cows were also among those treated for retained placenta. All treated cows remained in the study with all treatments being recorded. In total, 24 cows were treated with antibiotics (for any reason) in the period from calving to first examination, and 17 cows were treated in the period between the first and the second examination.

\subsection{Clinical examinations}

All cows were clinically examined twice after calving by three herd veterinarians (one in Herd 1 and 3, one in Herd 2 and 4, one in Herd 5). The first examination was made on average 8 days p.p. (range $0-19$ days) with the majority (85\%) of the cows being examined between 5 and 11 days p.p. At this time all fresh cows were examined by the herd veterinarian according to the standardized procedure specified in the Danish law regarding herd health agreements. According to this law, fresh cows must be examined once in the period 5-19 days after calving, and they must, among other things, have a scoring of uterine discharge according to a legally specified scoring system. The uterine scores are the only registrations addressed in this paper. This uterine scoring system is a combined evaluation of amount, color, smell, pus content and consistency of the vaginal discharge (Table 1), and the principles of this scoring system are comparable to those in the scoring system by Williams et al. (2005). The uterine score is given by scoring discharge manually withdrawn from the vagina. If this discharge smells abnormal, a score of at least 5 must be given.

The cows had their second examination on average 28 days p.p. (range $22-38$ days) with the majority (72\%) of the cows examined between 26 and 30 days p.p. At this examination only a uterine sample was taken. The average number of days between the two examinations was 19 (range 11-30 days) with the interval being 19-23 days for the majority of cows (66\%).

\subsection{Uterine condition}

At the first examination, each cow was given one of the 10 uterine scores (Table 1). For data analysis cows were

\section{Table 1}

Outline of the clinics defining the uterine score system used routinely on cows 5-20 days after calving in Denmark.

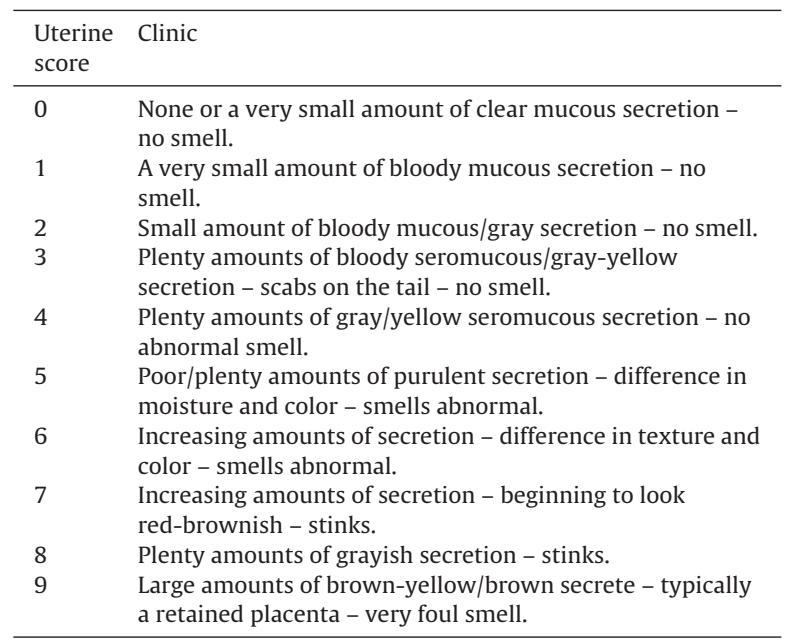

Modified and translated from http://www.landbrugsinfo.dk/Kvaeg/Filer/ nysr_vej_klinisk.pdf (in Danish).

grouped into the three overall uterine conditions: good (uterine score 0 and $1 ; 58$ cows (49\%)); medium (uterine score 2,3 and $4 ; 40$ cows (34\%)); bad (uterine score 5, 6, 7, 8 and $9 ; 20$ cows $(17 \%))$.

\subsection{Uterine sample collection}

Uterine samples were taken from all cows at both first and second clinical examination, using an instrument developed at the Estonian University of Life Sciences. The instrument consisted of an outer guiding tube and an inner rod mounted with a small sterile brush (Uterobrush, Medscand Medical AB, Malmö, Sweden). The brush has a small ball at its outer end, which fits into the guiding tube cap, thereby closing the tube and avoiding contamination of the brush during its insertion through vagina and cervix. Before use, the whole instrument was sterilized by boiling for $10 \mathrm{~min}$. At each sampling the cow was restrained and its vulvar lips were cleaned using a dry paper towel. By rectal manipulation of the cervix, the instrument was then guided through the cervix into the uterus lumen, where the brush was protruded and rotated several times to collect material. The brush was then withdrawn into the guiding tube to ensure uncontaminated collection of uterine discharge. After sampling, the brushes were aseptically separated from the device into separate plastic containers marked with individual cow numbers. The brushes were frozen $\left(-19^{\circ} \mathrm{C}\right)$ within $3 \mathrm{~h}$ from sampling, and were later transported on dry ice to the lab. After each use the instrument was cleaned in lukewarm soap water, a new Uterobrush was mounted and the whole instrument was sterilized by boiling.

\subsection{Uterine sample analysis}

For DNA extraction from the uterine samples they were mixed with phosphate-buffered saline, followed by centrifugation at $20,000 \times \mathrm{g}$ for $10 \mathrm{~min}$ at $5^{\circ} \mathrm{C}$. From each 
sample, equal amounts of DNA were extracted. The supernatant was discarded and the pellet re-suspended in $200 \mu \mathrm{l}$ phosphate-buffered saline and $350 \mu$ l solution A from Easy DNA kit (Invitrogen, Paisley, UK) added together with $400 \mathrm{mg} 100 \mu \mathrm{m}$ Zirkonia-silica beads (BioSpec Products Inc., Bartlesville, US). The bacterial cells were then broken in a mini beadbeater (Biospec Products Inc.) for $4 \mathrm{~min}$. Hereafter the DNA was extracted with the Easy DNA kit as described by the manufacturer. The DNA concentration was measured by optical density and the DNA was adjusted to a concentration of $5 \mu \mathrm{g}$ of DNA/ml.

A polymerase chain reaction (PCR) was performed with fluorescence tagged primers for $16 \mathrm{~S}$ rRNA gene, and the PCR products were purified as previously described (Mølbak et al., 2007). The PCR products were digested with the restriction enzyme Hhal to yield fluorescently labeled terminal restriction fragments (TRFs). The TRFs were analyzed by polyacrylamide gel electrophoresis according to the procedure described in Mølbak et al. (2007).

Identification of TRFs with naming of the bacteria was done by cloning and sequencing the DNA in two samples from each herd, one from a cow with uterine score 0 , and one from a cow with a greater uterine score (5-9). The number of samples was limited because of economic considerations. Cloning and sequencing was done as described previously (Mølbak et al., 2007).

The TRF profiles and 16S rRNA gene sequences were analyzed using the software BioNumerics (Applied Maths, Kortrijk, Belgium). The 16S rRNA gene sequences have been assigned to their taxonomic names in RDP classifier (http://rdp.cme.msu.edu). Based on 99\% similarity, representative operational taxonomic units were created and were submitted to the National Center for Biotechnology Information $(\mathrm{NCBI})$, where they received their respective accessions numbers. In Section 3 of this manuscript, the table includes both bacterial names and their respective TRF sizes. If specific naming was not completed this is indicated as undetermined (UD) and only the TRF size is stated.

\subsection{Milk sampling and analysis}

Milk samples from each cow were taken by the farmer once a week from calving to 8 weeks p.p. In the two herds using milking parlors, samples were taken at morning milking where milk from the individual cow was stripped directly from the teat into a plastic collection tube after removal of the milking equipment. In the two herds using robot milking, the milk samples were taken at varying times after milking, but also here milk was stripped directly from the teat into the plastic collection tube. In the fifth herd, proportional whole milk samples were collected automatically during milking in the robotic milking system. All milk samples from each cow were frozen $\left(-19^{\circ} \mathrm{C}\right)$ for later analysis.

Milk progesterone was determined using the Ovucheck ELISA-kit (Biovet Inc., St. Hyacinthe (Oc), J2S BW2 Canada). Milk samples were pipetted, diluted and distributed using a Biomek 2000, Laboratory Automation Workstation, Beckman Coulter. Milk samples (here $25 \mu \mathrm{l}$, diluted $1+2$ with water) were handled according to the manufacturer's instructions. Plates were read using a spectrophotometer/fluorometer (Fluostar, BMG Labtechnologies, $575 \mathrm{~nm}$ ). Analyses were performed in 96 well plates with two times seven standards $(0-30 \mathrm{ng} / \mathrm{ml})$ locally made from milk from ovariectomized cows and ethanolic progesterone solutions, and with two times two control samples (3 and $15 \mathrm{ng} / \mathrm{ml}$ ) used for every analysis and plate. Inter-assay precision was 18.6 and $13.0 \mathrm{CV} \%$, for lesser and greater control samples, respectively $(n=38 ; n=2)$, while intraassay precision was 10.6 and $8.1 \mathrm{CV} \%$ for lesser and greater control samples, respectively $(n=2 ; n=38)$. The accuracy of lesser control ( $3 \mathrm{ng} / \mathrm{ml})$ was $2.35 \pm 0.74(\mathrm{SD})(n=76)$, and for greater control $(15 \mathrm{ng} / \mathrm{ml})$ it was $15.75 \pm 1.69$ (SD) $(n=76)$.

\subsection{Milk progesterone profiles}

The analysis of milk samples from each cow resulted in progesterone profiles that were used to determine the length of p.p. anovulation. The cow was defined to have started estrous cycling, when the progesterone concentration was above $4 \mathrm{ng} / \mathrm{ml}$ (Friggens and Chagunda, 2005) for two consecutive samples, where the day of the second milk sample above $4 \mathrm{ng} / \mathrm{ml}$ was set as the actual starting day, due to the previously mentioned variation in milk sampling method in the herds.

Based on the cow's actual starting day of estrous cycling, the length of p.p. anestrous was calculated. A new variable was then made to define the length of the p.p. anovulation as normal or long. The definition was made by looking at the 90th percentile of length of p.p. anestrous, which was 56 days in the cows in this study. A p.p. anestrous $\leq 56$ days was therefore defined as normal, whereas a length of more than 56 days was defined as long.

\subsection{Statistical analysis}

Of the 125 cows in this study, uterine samples from seven cows contained too little material to yield a sufficient result in the T-RFLP, so these cows were removed from all the analyses. The registrations regarding calving management were occasionally missing due to unknown causes, so these analyses were made on lesser number of cows. Lastly, 12 cows were removed from the analyses where length of p.p. anovulation was used, due to missing progesterone samples.

For the statistical analyses the program ' $R$ ' ( $R$ Development Core Team, 2010) was used, and the level of significance was $5 \%$. In analyses regarding bacterial composition, principal component analysis (PCA) was applied, using the prcomp function. The raw data were composed of each cow's percentage-wise distributions of its different TRF sizes, so the sum of percentages for TRFs for each cow was 100 . This dataset contained 186 different TRF sizes, so PCA was chosen for this dataset, because it is a useful method to reduce this very high number of variables (Ringner, 2008), and because it is a strong tool for comparison of complex microbial communities (Abdo et al., 2006; Dollhopf et al., 2001; Kaplan et al., 2001). In addition to reduce the dimension of the original dataset, an advantage of the PCA is that you obtain a dataset with 
variables (PCs) that are uncorrelated with each other, due to the orthogonal construction. This is in contrast to the original dataset, where it must be assumed that there is some correlation between the variables.

\subsubsection{Construction of principal components}

The original variables (TRF sizes) were used to construct a new set of variables, the so-called principal components (PCs). A subset of these PCs can then be used for further analysis. Each individual uterine sample contributed to the construction of each PC. In a PC the original variables are weighted in such a way that the resulting component explains as much of the variation in the original dataset as possible. Therefore the first PC (PC1) explains the most variation of the original data, and the second PC (PC2, orthogonal to PC1) explains as much as possible of the remaining variation, not explained by PC1. Subsequent PCs are constructed in the same way, thereby explaining less and less of the variation in the original dataset. The same number of PCs is constructed as there are variables in the original dataset (here 186), but to reduce the dimension of the dataset, only the first few PCs are used for further analyses. In the present manuscript a combination of two criteria for determining the number of PCs chosen for further analysis were applied (Mardia et al., 1979): first the chosen PCs together must explain at least $90 \%$ of the total variation in the original dataset, and second each chosen component must explain at least $1 \%$ of the total variation. In the present study both of the criteria led to the same number of PCs chosen in each analysis.

Following the PCA a new dataset containing the chosen number of PCs was constructed, now with a smaller dimension than the original dataset. Each of the PCs can be seen as a new measure for composition of TRF sizes, in other words bacterial composition. In the subsequent analyses, the PCs can be evaluated together with the loadings for each PC, where the loadings indicate the weight of the original variables, in this case TRF sizes representing specific bacteria, in the composition of the PC.

\subsubsection{Analysis of principal components}

Testing for differences in the profile of bacterial species present in the different individual samples (hereafter referred to as bacteria composition) between the first and the second examination was done as follows: a PCA was performed as described above. The PCA resulted in a dataset with 20 PCs chosen (PC1 to PC20). Following this an analysis of the effect of examination number was made for each PC separately, starting with PC1, then PC2 and onwards. The analysis was made using a linear regression with the respective PC as the response variable and examination number as the explanatory variable.

For the main outcome (i.e. bacterial composition), the linear regression included the explanatory variables herd, days from calving, calving difficulty, retained placenta, use of clean bedding, length of p.p. anovulation and whether the uterine condition was classified as good, medium or bad. As the initial analysis showed that there was an effect of examination number on bacterial composition, the present analysis was made for each examination number separately. The original dataset was split into two, according to examination number, and separate PCAs were conducted for first and second examination, respectively, resulting in two new datasets. The dataset regarding the first examination consisted of 20 chosen PCs (PC1 to PC20), and the dataset regarding the second examination consisted of 15 chosen PCs (PC1 to PC15). Each of the chosen PCs was used as the response variable in linear regressions with the above-mentioned explanatory variables, starting with PC1, then PC2 and onwards.

To evaluate if antibiotic treatments had any effect on the bacterial composition in the uterus, separate linear regressions were built with the PCs as the response variable and treated/not treated as the explanatory variable. The scenarios considered were: (i) difference in bacteria composition at the first examination for cows treated/not treated in the period from calving to first examination; (ii) difference in bacteria composition at the second examination for cows treated/not treated in the period from calving to first examination; (iii) difference in bacteria composition at the second examination for cows treated/not treated in the period from first to second examination. In all the mentioned analyses Bonferroni's correction for multiple tests was used to avoid the problem that calculating numerous correlations increases the risk of erroneously concluding the presence of a significant correlation.

\subsubsection{Additional analyses}

To test which variables had an effect on the response variable (uterine score, which is a class variable from 0 to 9 (Table 1)), multinomial log-it models were applied using the multinom function. The explanatory variables tested were herd, calving difficulty, retained placenta, parity and herd $\times$ calving difficulty. The interaction herd $\times$ calving difficulty was included in the analysis because the scoring of calving difficulty was possibly influenced by the observer, i.e. to which herd the cow belonged. The same method was used in analyzing which variables had an effect on the variable calving difficulty, as this is also a class variable. The explanatory variables analyzed here were herd, parity, milk fever, use of calving pen, number of cows in calving pen at the time of calving and time spent in calving pen before calving.

\section{Results}

\subsection{Bacterial flora}

Bacteria were found in all cows at both first and second examination. The initial analyses were performed to investigate possible differences in bacteria composition between examinations. The examination number had an effect on PC1 and PC7 $(P=0.002$ and $P=0.025$, respectively), whereas the analyses for the remaining PCs showed no significant effect of examination number. The first PC (PC1) accounted for $29.1 \%$ of the total variation in the profile of bacterial species present in the different individual samples (referred to as bacterial composition). From the loadings concerning this PC it was found, that the bacteria Pseudomonas/Acinetobacter and Fusobacterium necrophorum were given the greatest weight. The seventh PC (PC7) only accounted for $3.75 \%$ of the total variation in the 
original dataset regarding bacteria composition. From this analysis it can be assumed that there were differences in bacteria composition between the first and second examination, and the following analyses were, therefore, done separately for the first and the second examination.

\subsubsection{Bacterial flora at first and second examination}

In the data-set regarding the first examination the effects of the variables herd, days from calving, clean bedding, calving difficulty, retained placenta, antibiotic treatment before first examination, length of p.p. anovulation, and uterine condition (good/medium/bad) on each chosen PC were analyzed. The only significant variable was herd, which was significant in the analyses regarding PC6 and PC12. Together, these 2 PCs accounted for $7.3 \%$ of the total variation in bacteria composition, with PC6 accounting for $5.0 \%$ and PC12 accounting for $2.3 \%$. From the loadings it was seen that PC6 mainly gave weight to E. coli, while PC12 mainly gave weight to a bacterium with the TRF size 230.6 that was not found in the clone library (data not shown).

To investigate whether the herd effect was due to different histories of metritis incidence between the five herds (high or low), further investigation of the linear model was made. This showed that the significant herd effect on PC6 was due only to a significant difference between Herd 2 and the remaining herds and not between any other herds. The significant herd effect on PC12 was due only to significant differences between Herd 3 and the remaining herds and not between any other herds. Therefore, the herd effect was not due to history of disease incidence, as there then would have been no differences between the low incidence herds (1, 2 and 5$)$, and no differences between the high incidence herds ( 3 and 4 ).

In the data regarding the second examination the effects of the variables herd, days from calving, clean bedding, calving difficulty, retained placenta, antibiotic treatment before first examination, antibiotic treatment from first to second examination, and length of p.p. anovulation on each chosen PC was tested. Again herd was the only significant variable in the linear model for PC2 and PC11 that accounted for $15.6 \%$ and $1.6 \%$ of the total variation, respectively. Investigation of the loadings showed that PC2 mainly gave weight to Arcanobacterium. As for the first examination, the herd effect was investigated further, showing that the effect of herd on PC2 was due to differences between Herd 1 and the rest, while the effect on PC11 was due to differences between Herd 5 and the rest. Again the herd effect was not found to be due to historical metritis incidence.

\subsubsection{Change in bacterial flora between first and second examination}

To get an indication of the number of bacterial species present in the uterus of the p.p. cows in this study, the number of TRFs was used as a proxy for the number of bacterial species, and was investigated for each examination in each herd. There was a large variation in number of TRFs in the herds (from 1 to 50), with an average number from both examinations of $21 \pm 1.4,11 \pm 1.2,16 \pm 1.1,15 \pm 1.0$ and $8 \pm 0.6$ in Herd 1, 2, 3, 4 and 5, respectively. No clear differences in number of TRFs were found between first and second examinations. The numbers given here illustrate that a large and variable number of bacterial species was found in each herd and at both examinations. The most common bacteria from each herd at each examination are shown in Table 2.

In all five herds the bacteria $F$. necrophorum, Pseudomonas/Acinetobacter and Bacteroides/Sphingobacterium/Prevotellaceae were among the most frequent at both first and second examination. From the first to the second examination there was a decrease in percentage of F. necrophorum in all herds except Herd 4, while there was an increase in percentage of Pseudomonas/Acinetobacter in all five herds.

\subsection{Influence of calving management}

The initial analysis of variance showed that there was no significant effect of calving difficulty on bacterial composition at either first or second examination. Then effect of calving difficulty was tested with uterine score as the response variable. The explanatory variables tested were herd, calving difficulty, retained placenta, parity and herd $\mathrm{x}$ calving difficulty. The model with uterine score as response variable and all explanatory variables could be reduced stepwise, and only the effect of herd was significant for uterine score $(P<0.001)$. If uterine score as a response variable was replaced by its subgroups good, medium and bad, both herd $(P<0.001)$, calving difficulty $(P=0.016)$ and retained placenta $(P=0.003)$ had an effect.

An analysis was made to test which variables had an effect on the parameter calving difficulty. The explanatory variables tested were herd, parity, milk fever, use of calving pen, number of cows in calving pen at the time of calving and time spent in calving pen before calving. The model containing all explanatory variables was reduced stepwise, and only herd and time spent in calving pen before calving had an effect on the parameter for calving difficulty $(P<0.001$ and $P=0.006$, respectively).

\section{Discussion}

This is one of the first studies where uterine bacterial flora in p.p. dairy cows has been described based on identification of the bacterial DNA using the T-RFLP method (Santos et al., 2011). This method has advantages compared to traditional bacterial culture as it detects DNA and, therefore, indicates all bacteria present in a sample, regardless of their growth potential, and not only those bacteria that can be cultured on a given medium (Amann et al., 1995; Kalmbach et al., 1997). Still, the T-RFLP method does not always determine the exact species of bacteria directly from the output, even when applying further analyses such as cloning and sequencing (Abdo et al., 2006). In the present research, this is illustrated by the obtained TRF size of 206.48, that could correspond to Pseudomonas, which was found to have TRF size 205 by cloning and sequencing, or it could correspond to Acinetobacter, which was found to have TRF size 208 by cloning and sequencing. Due to this, both potential bacterial names are given, and the same bacteria name can occur with different corresponding TRF sizes. 
Table 2

The percentagewise most common bacteria ${ }^{\mathrm{a}}$ at first (avg. 8 days p.p.) and second (avg. 28 days p.p.) clinical examination in the 5 herds.

\begin{tabular}{|c|c|c|c|c|c|c|c|c|c|c|c|}
\hline \multirow[t]{3}{*}{ Bacteria name ${ }^{b}$} & \multirow[t]{3}{*}{ TRF size } & \multirow{2}{*}{\multicolumn{2}{|c|}{$\frac{\text { Herd } 1}{\text { Examination }}$}} & \multirow{2}{*}{\multicolumn{2}{|c|}{$\frac{\text { Herd } 2}{\text { Examination }}$}} & \multirow{2}{*}{\multicolumn{2}{|c|}{$\frac{\text { Herd } 3}{\text { Examination }}$}} & \multirow{2}{*}{\multicolumn{2}{|c|}{$\frac{\text { Herd } 4}{\text { Examination }}$}} & \multirow{2}{*}{\multicolumn{2}{|c|}{$\frac{\text { Herd } 5}{\text { Examination }}$}} \\
\hline & & & & & & & & & & & \\
\hline & & First & Second & First & Second & First & Second & First & Second & First & Second \\
\hline Pseudomonas/Acinobacter & 206.48 & 8.6 & 11.0 & 4.9 & 23.5 & 7.1 & 18.5 & 9.0 & 15.3 & 18.2 & 26.0 \\
\hline Fusobacteriumnecrophorum & 82.10 & 10.6 & 3.1 & 19.9 & 10.6 & 18.3 & 11.8 & 16.2 & 17.9 & 21.5 & 10.2 \\
\hline Sphingobacterium/Bacteroides/Prevotellaceae & 100.20 & 7.1 & 9.9 & 5.0 & 6.4 & 4.8 & 4.1 & 9.3 & 3.7 & 7.0 & 8.2 \\
\hline Arcanobacterium & 483.65 & 4.5 & 4.3 & & & & & & & & \\
\hline Brevundimonas & 331.90 & & & & & & & & & 5.4 & 6.4 \\
\hline Comamonas & 567.26 & & & & & & 4.9 & & 6.6 & 5.1 & 8.2 \\
\hline E. coli & 373.15 & & & 9.2 & & & & & & & \\
\hline Peptostreptococcus & 62.79 & & & & & 4.8 & & & & & \\
\hline Sphingobacterium/Bacteroides & 104.51 & & 4.1 & 13.1 & & & & & & & \\
\hline Stentrophomonas & 215.96 & & & & 4.4 & & 4.9 & & & & 9.0 \\
\hline Streptococcus & 583.74 & 6.0 & & & & 7.8 & 2.7 & & & & \\
\hline $\mathrm{UD}^{\mathrm{c}}$ & 98.49 & & & & 8.1 & & & 7.6 & 7.1 & & \\
\hline$U^{c}$ & 200.80 & & & & & & & 4.5 & 6.1 & & \\
\hline$U^{c}$ & 230.60 & & & & & 5.6 & 2.4 & & & & \\
\hline Veillonella & 593.77 & 6.2 & & & & & & & & & \\
\hline
\end{tabular}

To establish the exact species it would have been necessary to do next-generation sequencing on the amplicons of the 16S rRNA gene or the microbiome. Due to economic considerations the exact bacterial names were not pursued.

\subsection{Uterine flora in relation to herd and time after calving}

The bacterial flora was found to differ between the five herds in the present study. Such a herd difference has not been shown before, and this difference is of importance to consider both when interpreting results from uterine samplings and when selecting antibiotic treatments, as treatments possibly should differ among herds.

The findings here that the uterine flora in the p.p. cow consists of many species are well in line with other studies (Bekana et al., 1994; Huszenicza et al., 1999; Kask et al., 1998; Sheldon et al., 2002). A recent study also using culture-independent methods for describing and comparing uterine bacterial composition in Holstein dairy cows showed, that the bacterial diversity in uteri was greater and more complex than previously described using traditional culture (Santos et al., 2011). This is also demonstrated in the present study but on an even larger number of cows. In the present study, bacteria were present in $100 \%$ of cows at the second examination approximately 28 days after calving. This is a greater prevalence compared to previous studies (Huszenicza et al., 1999; Sheldon et al., 2008), and the discrepancy might very well be a reflection of the use of the T-RFLP method compared to bacterial culture. Culture-independent methods of analysis generally detect a much greater number of microorganisms than culture (Santos et al., 2011; Zoetendal et al., 2004) due to limitations in the culturing techniques (Zoetendal et al., 2004). Therefore culture-independent methods are now widely used for studying complex microbial communities in many different species (Mølbak et al., 2007; Rampersaud et al.,
2012; Santos et al., 2011). It must be noted that as T-RFLP also detects dead or damaged bacteria, however, not all the bacteria found might necessarily cause the disease. The fraction of dead bacteria, however, must be assumed to be minor and to be a part of the same population as the live bacteria.

At first examination, on average 8 days after calving, the most common bacterium in all herds was F. necrophorum. This organism is an obligate anaerobe, inhabits mucous membranes in both humans and animals, and is known to cause diseases in cattle such as interdigital phlegmon, necrotic laryngitis and necrotic vaginitis, usually as part of a mixed infection. It is also commonly isolated from the uterus of cattle, especially after a complicated calving with e.g. retained placenta and/or uterine infections (Bekana et al., 1996; Huszenicza et al., 1999; Santos et al., 2011). It was therefore quite surprising, that $F$. necrophorum was found to such a large degree even in healthy animals in this study. One reason could be, that $F$. necrophorum is more pathogenic when found together with $A$. pyogenes (Ruder et al., 1981), a bacterium that was not often found in the present study.

At second examination the most common bacteria were Pseudomonas/Acinetobacter in four of the five herds, whereas $F$. necrophorum was still the most common bacteria in Herd 4. Pseudomonas/Acinetobacter are strict aerobe gram-negative bacteria, widespread in the environment. Acinetobacter is mostly known to be a potential pathogen, occasionally reported to cause disease in immune-compromised humans (Bergogne-Berezin and Towner, 1996). Pseudomonas is, however, known to be involved in a variety of diseases. The finding in the present study that such bacteria, rarely reported to cause uterine disease, are so common in the uterus of cattle is in agreement with the results of Santos et al. (2011).

Arcanobacterium is frequently found in uterine samples from dairy cows and impairs later reproduction (Bonnett 
et al., 1991; Griffin et al., 1974; Jadon et al., 2005; Takács et al., 1990). Arcanobacterium was not often found in the present study, and the low prevalence of Arcanobacterium might also be the reason for no relation between bacterial flora and length of p.p. anovulation. Further, there were no specific bacteria or flora in cows with pathological, malodorous uterine discharge (score $\geq 5$ ) in the present study, as has been indicated by others (Griffin et al., 1974; Huszenicza et al., 1999; Williams et al., 2005). In another analysis, using the data from this study (Mølbak et al., 2011, unpublished), uterine scores were used to divide the cows into healthy $(\leq 3)$ and $\operatorname{sick}(\geq 4)$, and the analysis was made solely on the relative presence or absence of the different bacteria. With these definitions, there was a greater prevalence of $F$. necrophorum in the sick animals (uterine score $\geq 4$ ). This illustrates the importance of disease definitions for the conclusions attained.

In the present analysis there was a difference in bacterial flora between first and second examination. This was expected, since variation in bacterial flora with time from calving is also shown in other studies (Bekana et al., 1996; Griffin et al., 1974; Hussain et al., 1990). There seems to be an overabundance of gram-negative bacteria in the cows in our study relative to other reports. A shift from a gramnegative to gram-positive flora over the first 4-5 weeks postpartum has previously been described (Hussain et al., 1990). More anaerobic or facultative anaerobic bacteria were also detected in the present study at first examination compared to second examination. Others have found an anaerobic flora up to 8 weeks p.p. (Bekana et al., 1994, 1996; Kask et al., 1998). The findings in the present study could indicate that the uterine environment shifts from anaerobic to aerobic during the involution process, something to consider if bacterial cultures are to be made.

\subsection{Connection between uterine flora and uterine scoring system used in Denmark}

In the present study, there was not any relationship between the uterine flora, determined by the T-RFLP method, and the uterine scoring system used in Denmark. This is supported by a recent study, where only a slight agreement between major uterine bacterial pathogens and score of vaginal discharge was found (McDougall et al., 2011). This is in contrast to Williams et al. (2005), however, where scoring of the vaginal discharge did reflect uterine bacterial flora. For the analyses we grouped the uterine scores into three groups of uterine condition that were comparable to those of Williams et al.(2005), but even with this reduction in the number of classes in the Danish uterine scoring system, no relation to bacterial flora was found. This is an aspect to consider for future analyses on the Danish scoring system. A reason for not seeing any relations could be that we did not have an indication of the exact amount of bacteria present, as the T-RFLP method is merely semi-quantitative (Osborn et al., 2000). Thus, shifts in bacteria populations with uterine score may be masked by the continued presence of species in non-significant but detectable quantities. This semi-quantitative aspect of the T-RFLP method may be a limitation in respect to examining bacterial population shifts. This would call for the combination of the T-RFLP method with another method better suited to quantify bacteria amount, such as quantitative real time PCR with general bacterial primers or species specific primers (Matsuki et al., 2004).

Finally, it should be mentioned that another contributor to the non-significant relations between vaginal discharge and uterine bacterial flora could be that vaginal discharge may not always reflect inflammation in the uterus, but rather be due to cervicitis or vaginitis (Dubuc et al., 2010).

\subsection{Important management variables}

In the present study, there was no significant effects of management factors on uterine bacterial composition indicating that, although there may be effects of factors such as calving difficulty, these management factors did not have so pronounced effects that they could be detected with the present sample size of 125 cows. Indeed, from our analyses it appears that the more assistance required at calving, the greater risk of having a poor uterine score. This seems plausible, as manipulations of the calf in the birth canal must increase the risk of introducing bacteria (Bruun et al., 2002) and might also damage the soft tissues in the birth canal, thereby increasing the inflammatory response. Furthermore we could not see any effects of the use of fresh, clean bedding in the pen before calving on bacteria composition. The reason for this could be that the hygienic standards in the participating herds and particularly in the calving pens were already high. These previous findings are consistent with others (Noakes et al., 1991; Potter et al., 2010), where the hygienic environment had no influence on either the quantitative or qualitative uterine bacterial flora or prevalence of endometritis. One explanation might be that the effect of hygiene is hidden in the herd parameter. Some of the herd differences might also come from the fact that different persons were involved in the data registration (Lastein et al., 2009), but still it was very important for us to study these factors under typical commercial conditions. Furthermore, a recent study documented moderate intra-observer repeatability of scoring vaginal discharge, and showed that the experience of the investigator had no effect on the scoring (Leutert et al., 2012).

\section{Conclusion}

The bacterial flora was composed of many different species, and composition was dependent on herd and time from calving. For all five herds the bacteria F. necrophorum, Pseudomonas/Acinetobacter and Bacteroides/Sphingobacterium/Prevotellaceae were among the most common at both first and second examination. Neither calving difficulty nor calving management was significant for bacterial composition. The uterine condition, assessed by the Danish uterine score system, was influenced by herd, calving difficulty and retained placenta, but was not related to uterine bacterial flora.

\section{Acknowledgements}

The authors thank Kitt Dupont and Tim Kåre Jensen (National Veterinary Institute, Technical University of 
Denmark) for excellent assistance during uterine sample and DNA analysis. The authors also thank the participating farmers, veterinarians and technical staff for their involvement, as well as statistical consultant Malene Juul Rasmussen (Agrotech A/S, Institute for Agri Technology and Food Innovation, Denmark) for help on the statistical analyses. The study was financed by the Danish Ministry of Science, Technology and Innovation and the Knowledge Centre for Agriculture, Cattle. Support for the development and production of the instruments for uterine sample collection was provided by the Estonian Science Foundation and the Estonian Ministry of Agriculture. The funding sources had no involvement in any parts of the study.

\section{References}

Abdo, Z., Schüette, U.M.E., Bent, S.J., Williams, C.J., Forney, L.J., Joyce, P., 2006. Statistical methods for characterizing diversity of microbial communities by analysis of terminal restriction fragment length polymorphisms of 16S rRNA genes. Environ. Microbiol. 8, 929-938.

Amann, R.I., Ludwig, W., Schleifer, K.H., 1995. Phylogenetic identification and in situ detection of individual microbial cells without cultivation. Microbiol. Rev. 59, 143-169.

Bekana, M., Jonsson, P., Ekman, T., Kindahl, H., 1994. Intrauterine bacterial findings in postpartum cows with retained fetal membranes. J. Vet. Med. Ser. A 41, 663-670.

Bekana, M., Jonsson, P., Kindahl, H., 1996. Intrauterine bacterial findings and hormonal profiles in post-partum cows with normal puerperium. Acta Vet. Scand. 37, 251-263.

Bergogne-Berezin, E., Towner, K.J., 1996. Acinetobacter spp. as nosocomial pathogens: microbiological, clinical, and epidemiological features. Clin. Microbiol. Rev. 9, 148-165.

Bonnett, B.N., Martin, S.W., Gannon, V.P.J., Miller, R.B., Etherington, W.G., 1991. Endometrial biopsy in Holstein-Friesian dairy cows. III. Bacteriological analysis and correlations with histological findings. Can. J. Vet. Res. 55, 168-173.

Bruun, J., Ersbøll, A.K., Alban, L., 2002. Risk factors for metritis in Danish dairy cows. Prev. Vet. Med. 54, 179-190.

Dolezel, R., Palenik, T., Cech, S., Kohoutova, L., Vyskocil, M., 2010. Bacterial contamination of the uterus in cows with various clinical types of metritis and endometritis and use of hydrogen peroxide for intrauterine treatment. Vet. Med. Czech. 55, 504-511.

Dollhopf, S.L., Hashsham, S.A., Tiedje, J.M., 2001. Interpreting 16S rDNA T-RFLP data: application of self-organizing maps and principal component analysis to describe community dynamics and convergence. Microb. Ecol. 42, 495-505.

Dubuc, J., Duffield, T.F., Leslie, K.E., Walton, J.S., LeBlanc, S.J., 2010. Definitions and diagnosis of postpartum endometritis in dairy cows. J. Dairy Sci. 93, 5225-5233.

Elliott, L., McMahon, K.J., Gier, H.T., Marion, G.B., 1968. Uterus of the cow after parturition: bacterial content. Am. J. Vet. Res. 29, 77-81.

Fredriksson, G., Kindahl, H., Sandstedt, K., Edqvist, L.E., 1985. Intrauterine bacterial findings and release of PGF2-alpha in the postpartum dairy cow. J. Vet. Med. Ser. A 32, 368-380.

Friggens, N.C., Chagunda, M.G.G., 2005. Prediction of the reproductive status of cattle on the basis of milk progesterone measures: model description. Theriogenology 64, 155-190.

Griffin, J.F.T., Hartigan, P.J., Nunn, W.R., 1974. Non-specific uterine infection and bovine fertility. I. Infection patterns and endometritis during the first seven weeks post-partum. Theriogenology 1, 91-106.

Hussain, A.M., Daniel, R.C.W., O’Boyle, D., 1990. Postpartum uterine flora following normal and abnormal puerperium in cows. Theriogenology 34, 291-302.

Huszenicza, G., Fodor, M., Gacs, M., Kulcsar, M., Dohmen, M.J.W., Vamos, M., Porkolab, L., Kegl, T., Bartyik, J., Lohuis, J.A.C.M., Janosi, S., Szita, G., 1999. Uterine bacteriology, resumption of cyclic ovarian activity and fertility in postpartum cows kept in large-scale dairy herds. Reprod. Domest. Anim. 34, 237-245.

Jadon, R.S., Dhaliwal, G.S., Jand, S.K., 2005. Prevalence of aerobic and anaerobic uterine bacteria during peripartum period in normal and dystocia-affected buffaloes. Anim. Reprod. Sci. 88, 215-224.

Kalmbach, S., Manz, W., Szewzyk, U., 1997. Isolation of new bacterial species from drinking water biofilms and proof of their in situ dominance with highly specific $16 \mathrm{~S}$ rRNA probes. Appl. Environ. Microbiol. 63, 4164-4170.

Kaplan, C.W., Astaire, J.C., Sanders, M.E., Reddy, B.S., Kitts, C.L., 2001. 16 S Ribosomal DNA terminal restriction fragment pattern analysis of bacterial communities in feces of rats fed Lactobacillus acidophilus NCFM. Appl. Environ. Microbiol. 67, 1935-1939.

Kask, K., Kindahl, H., Gustafsson, H., 1998. Bacteriological and histological investigation of the postpartum bovine uterus in two Estonian dairy herds. Acta Vet. Scand. 39, 423-432.

Kitts, C.L., 2001. Terminal restriction fragment patterns: a tool for comparing microbial communities and assessing community dynamics. Curr. Issues Intest. Microbiol. 2, 17-25.

Lastein, D.B., Vaarst, M., Enevoldsen, C., 2009. Veterinary decision making in relation to metritis-a qualitative approach to understand the background for variation and bias in veterinary medical records. Acta Vet. Scand. 51.

Leutert, C., von Krueger, X., Plöntzke, J., Heuwieser, W., 2012. Evaluation of vaginoscopy for the diagnosis of clinical endometritis in dairy cows. J. Dairy Sci. 95, 206-212.

Mardia, K.V., Kent, J.T., Bibby, J.M., 1979. Multivariate Analysis. Academic Press, London.

Matsuki, T., Watanabe, K., Fujimoto, J., Kado, Y., Takada, T., Matsumoto, K., Tanaka, R., 2004. Quantitative PCR with 16S rRNA-gene-targeted species-specific primers for analysis of human intestinal Bifidobacteria. Appl. Environ. Microbiol. 70, 167-173.

McDougall, S., Hussein, H., Aberdein, D., Buckle, K., Roche, J., Burke, C., Mitchell, M., Meier, S., 2011. Relationships between cytology, bacteriology and vaginal discharge scores and reproductive performance in dairy cattle. Theriogenology 76, 229-240.

Mølbak, L., Thomsen, L.E., Jensen, T.K., Bach Knudsen, K.E., Boye, M., 2007. Increased amount of Bifidobacterium thermacidophilum and Megasphaera elsdenii in the colonic microbiota of pigs fed a swine dysentery preventive diet containing chicory roots and sweet lupine. J. Appl. Microbiol. 103, 1853-1867.

Noakes, D.E., Wallace, L., Smith, G.R., 1991. Bacterial flora of the uterus of cows after calving on two hygienically contrasting farms. Vet. Rec. $128,440-442$.

Osborn, A.M., Moore, E.R.B., Timmis, K.N., 2000. An evaluation of terminalrestriction fragment length polymorphism (T-RFLP) analysis for the study of microbial community structure and dynamics. Environ. Microbiol. 2, 39-50.

Potter, T.J., Guitian, J., Fishwick, J., Gordon, P.J., Sheldon, I.M., 2010. Risk factors for clinical endometritis in postpartum dairy cattle. Theriogenology 74, 127-134.

R Development Core Team, 2010. R: A Language and Environment for Statistical Computing.

Rampersaud, R., Randis, T.M., Ratner, A.J., 2012. Microbiota of the upper and lower genital tract. Semin. Fetal Neonatal Med. 17, 51-57.

Ringner, M., 2008. What is principal component analysis? Nat. Biotechnol. 26, 303-304.

Ruder, C.A., Sasser, R.G., Williams, R.J., Ely, J.K., Bull, R.C., Butler, J.E., 1981. Uterine infections in the postpartum cow. 2. Possible synergistic effect of Fusobacterium necrophorum and Corynebacterium pyogenes. Theriogenology $15,573-580$.

Santos, T.M.A., Gilbert, R.O., Bicalho, R.C., 2011. Metagenomic analysis of the uterine bacterial microbiota in healthy and metritic postpartum dairy cows. J. Dairy Sci. 94, 291-302.

Sheldon, I.M., Noakes, D.E., Rycroft, A.N., Pfeiffer, D.U., Dobson, H., 2002 Influence of uterine bacterial contamination after parturition on ovarian dominant follicle selection and follicle growth and function in cattle. Reproduction 123, 837-845.

Sheldon, I.M., Rycroft, A.N., Dogan, B., Craven, M., Bromfield, J.J., Chandler, A., Roberts, M.H., Price, S.B., Gilbert, R.O., Simpson, K.W., 2010. Specific strains of Escherichia coli are pathogenic for the endometrium of cattle and cause pelvic inflammatory disease in cattle and mice. PLoS ONE 5.

Sheldon, I.M., Lewis, G.S., LeBlanc, S., Gilbert, R.O., 2006. Defining postpartum uterine disease in cattle. Theriogenology 65, 15161530.

Sheldon, I.M., Williams, E.J., Miller, A.N.A., Nash, D.M., Herath, S., 2008. Uterine diseases in cattle after parturition. Vet. J. 176, 115-121.

Silva, E., Leitão, S., Tenreiro, T., Pomba, C., Nunes, T., Lopes da Costa, L., Mateus, L., 2009. Genomic and phenotypic characterization of Escherichia coli isolates recovered from the uterus of puerperal dairy cows. J. Dairy Sci. 92, 6000-6010.

Takács, T., Gáthy, I., Macháty, Z., Bajmócy, E., 1990. Bacterial contamination of the uterus after parturition and its effect on the reproductive performance of cows on large-scale dairy farms. Theriogenology 33 , 851-865. 
Werner, A., Suthar, V., Plöntzke, J., Heuwieser, W., 2012. Relationship between bacteriological findings in the second and fourth week postpartum and uterine infection in dairy cows considering bacteriological results. J. Dairy Sci. 95, 7105-7114.

Williams, E.J., Fischer, D.P., Pfeiffer, D.U., England, G.C.W., Noakes, D.E., Dobson, H., Sheldon, I.M., 2005. Clinical evaluation of postpartum vaginal mucus reflects uterine bacterial infection and the immune response in cattle. Theriogenology 63, 102117.

Zoetendal, E.G., Collier, C.T., Koike, S., Mackie, R.I., Gaskins, H.R., 2004. Molecular ecological analysis of the gastrointestinal microbiota: a review. J. Nutr. 134, 465-472. 